\title{
13 \\ Paddle Your Own Canoe: Metaphors for Teaching Between the Tides
}

\author{
W. Alan Wright, Marie-Jeanne Monette, \& Beverley Hamilton \\ University of Windsor
}

Nearly twenty college and university voyageurs hailing from Atlantic Canada to the Pacific Coast and points in between, as well as intrepid pedagogues from institutions of higher education from Asia and Australia rendezvous at the Small Craft Aquatic Centre in Fredericton, New Brunswick, on the shores of the St. John River. The sun shines brightly on this warm, mid-June morning, and the water sparkles, inviting the assembled paddlers to embark on a fleeting voyage of discovery in the great Canadian out-of-doors. The group leader addresses the circle of eager life vest-clad participants as they stand, paddles in hand, in anticipation of the day's activity. "Welcome to this pre-conference workshop" begins the facilitator, "let us begin with a warm-up activity!" A casual observer of the scene would surely be perplexed: a canoe-based conference workshop activity? For professors of all ages, shapes, and sizes? What's this about?

\section{Introduction}

\begin{abstract}
mong the featured pre-conference workshops at Athe Society for Teaching and Learning in Higher Education (STLHE) Conference was Paddle Your Own Canoe. Inspired by the conference theme Between the Tides, the facilitators' intention was to explore the power of metaphor for teaching and learning in higher education, using canoeing as a concrete example. Although metaphors are often employed in
\end{abstract}

teaching and learning settings, instructors are seldom afforded the opportunity to explore the multiple meanings of metaphors in situ and with colleagues in a cross-disciplinary setting. The workshop leaders also set out to harness the power of concrete experience beyond four walls, reflection, conceptualization, and further experimentation as key elements of the morning's cycle of learning (Kolb, 1984). ${ }^{1}$ Field trips

\footnotetext{
${ }^{1}$ For those unfamiliar with it, Kolb's experiential learning cycle suggests four stages in learning, occurring cyclically: concrete experience, reflective observation, abstract conceptualization of what has been experienced, and the application of that conceptualization to a new round of activity, resulting in increasingly rich and refined understandings emerging from experience.
} 
and outdoor experiences are important, enriching elements of a holistic student learning and research experience (Tompkins, 1996, as cited in "Service Learning," 2009), and the facilitators predicated their workshop design on the notion that instructors can also benefit from this educational model as an integral part of their own professional development.

\section{The Role of Metaphors}

A scan of the literature on metaphors provides perspective on their general use since antiquity, their ubiquitous presence in many contexts in modern society, and their many and varied applications in classrooms and in teacher training and professional development.

A metaphor is defined as "a way of speaking in which one thing is expressed in terms of another, whereby this bringing together throws new light on the character of what is described" (Gorden, 1978, as cited in Gassner, 1999).

Historically, the metaphor can be found as "an effective tool" in the Bible, ancient Greek myths, and children's fairy tales. Further, metaphor has been used "to inspire, to make sophisticated theory more understandable, and to develop skill acquisition" (Gorden, 1978, as cited in Gassner, 1999). The approach has been adopted by coaches and leaders as well as teachers and scholars. The metaphor, then, as a "mental construction that helps us to structure our experience and to develop our imagination and reasoning" can be considered "pervasive in our daily life" (Lakoff \& Johnson, 1980, p. 3). Using metaphor can help us bring structure and meaning to our life and work experiences in what Johnson (1987) calls an "embodied schema" or an "image schema" (p. 29-30). Sfard (1994) sees the purpose of metaphor as providing a link between our concrete, lived experience and our abstract thought, breathing life into our imagination (as cited in Lim, 1999).

According to many authors, metaphors are an integral part of our daily life. How are they used in teaching and how can they be used in the professional development of teachers and university professors? Gassner (1999) notes that metaphors can be used in teaching to "make comparisons, to connect new concepts by more familiar ones, and just to be more creative to explain a theory, a concept, a philosophy." As one can imagine, there are myriad uses of the metaphor in the classroom, the lecture hall, and even in the laboratory. But the main interest of this paper is to explore the use of metaphors about teaching and the metaphors for teaching as seen by the teachers themselves. According to Thornbury (1991), "teachers, like other professionals, resort to and depend on the use of metaphor when it comes to verbalizing their experience: metaphors help them to see what is visible, to describe what otherwise would be indescribable" (p. 193). What is more, according to McDonald (1986), using a metaphor for our teaching "affects how we self-evaluate and revise our own pedagogy from year to year and from moment to moment."

A fascinating study of school teachers in Greece shed light on the metaphors commonly used to describe teaching in their context. The Greeks variously saw their roles as "gardener," "guide," "coach," "acrobat," "maestro," "cook," "sculptor," "locksmith," and surprisingly frequently, "flying a kite!" (Kasoutas \& Malamitsa, 2009). The study in question concludes that the application of metaphor has great promise as a way to gain understanding and insight into one's teaching as well as the practice of others in the profession. It also raises the difficulties associated with the use of metaphors such as widely varying interpretations by different researchers, ambiguities and problematic levels of abstraction (Glucksberg et al., 1992 as cited in Kasoutas \& Malamitsa, 2009; Lim 1999). This is an interesting qualification, but a full analysis of the limitations of the use of metaphor with teachers and university professors is beyond the scope of this essay.

\section{Paddle Your Own Canoe: Testing the Waters}

The authors of this essay led the canoeing workshop designed to explore canoeing as a metaphor for teaching. Placed into small teams, the teacher-participants were invited to explore specific aspects of canoeing as 
illustrated and described in an amusing and highly effective canoeing manual published in Canada in 1948 by R. H. Perry. The four small groups were given laminated copies of illustrations - a sampling of which appear on these pages, and asked to draw parallels between quite specific aspects of canoeing and elements of their college and university teaching lives. After an hour of canoeing and chatting, the participants beached the canoes and presented their reflections to members of the large group. Some examples of their thoughts follow.

One group was challenged to compare how to get in - and out of a canoe with certain aspects of teaching. On a sheet of instructions that accompany the sketch (Figure 1) provided, they were asked to "Prepare a five-minute presentation on this aspect of paddling as a metaphor for teaching." As was the

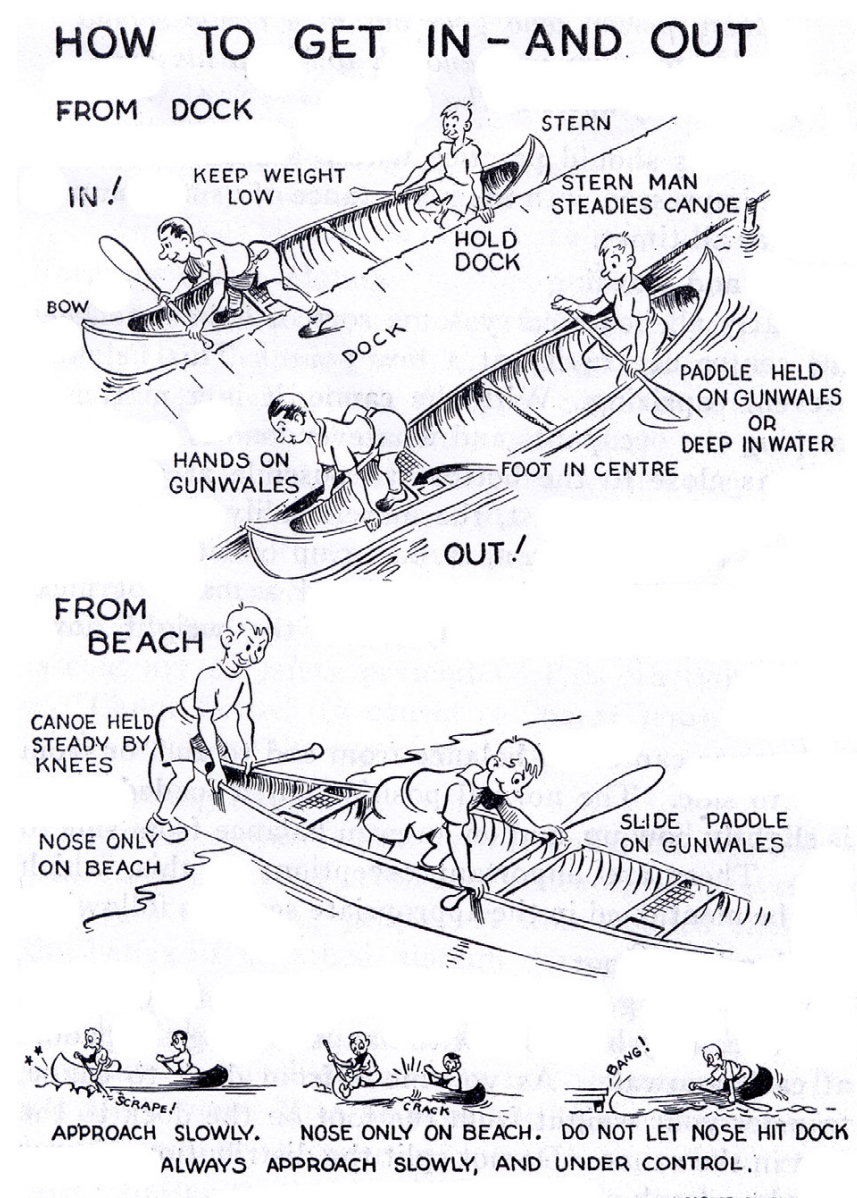

Figure $1^{2}$ case with all groups, the professors in group one were invited to consider making their point by choosing to "deliver a lecture, hold class, facilitate a seminar, make a group presentation, tell a story, perform a skit, develop a role play, engage in a conversation, describe or act out a critical incident, or employ any other strategy...to help your perspective come to life" (workshop materials, June 17, 2009).

The instruction sheet informed group one that: "As a paddler, it is important for you to learn the procedures for getting into and out of the canoe in a variety of circumstances... ( $t$ )here are a number of considerations for paddlers to be aware of if they are to enjoy successful outings and avoid mishap both for their canoes and for themselves in departing and in returning at the end of the excursion" (workshop materials, June 17, 2009). Although the workshop leaders expected group one to draw the parallels of getting into a lecture and closing a lecture, getting into the subject matter at the beginning of a term and wrapping up a semester, the group took a different approach. Team members decided to demonstrate the various ways one could go about teaching the concept of effective entry and exit of a canoe as an indication of the pedagogical choices they face every day in their teaching practice. The first team member proposed the experiential approach, noting it was the approach used in the workshop, whereby participants were invited to board the canoes with little or no prior instruction. A second team member mimicked a staid professor who emphasized the importance of a background lecture on the history of the canoe as a pre-requisite to teaching proper entry and exit techniques. A third team member illustrated the anecdotal method, recounting to the assembled learners how she had found it important to step into the middle of the canoe and to keep a low centre of gravity. A fourth team member stressed the importance of appealing to the emotional side of learning, inviting personal reflections on entry and exits and encouraging the use of learning logs.

The members of a second group were invited to examine a page of illustrations featuring notes of

\footnotetext{
${ }^{2}$ Reprinted from The Canoe and You (p. 18), by R. H. Perry, 1948, Toronto: J. M. Dent \& Sons Ltd.
} 
caution for hunters and fishermen using canoes for their outdoor sporting pursuits (Figure 2). The notes suggested that, just as canoeists must take special precautions in these circumstances, teachers would be well advised to take care in the pursuit of their classroom duties. The group two participants came up with the following parallels:

- just as it is important not to overload a canoe, it is important not to overload your class with information;

- just as it is important for canoeists to "keep a weather eye cocked for storms and early darkness" it is important for some teachers to avoid their tendency to become complacent and therefore miss warning signs of pedagogical pitfalls and, for other teachers, to be unaware of storm clouds brewing because of nervousness and a lack of confidence in the classroom;

- just as wearing heavy clothing in the late fall and early spring could represent potential danger for canoeists, teachers risk getting "bogged down" in the oppression of overload at the end of the fall and winter terms and certain students may have too much work/learning to accomplish at the end of a session; and

- just as paddlers should carry an extra paddle in the canoe, teachers should pack an extra tool when going to class, and be aware of the options for "extra paddles" in the pedagogical repertoire.

The two remaining groups applied lessons regarding proper stroking techniques, rescue readiness, and the importance of timing, rhythm, and pacing to the higher education setting. In the debriefing, the Small Craft Aquatic Centre instructor also contributed to the ongoing conversation, drawing a parallel between the "initial stability" of conventional pleasure canoes for beginners and the predictability/ limits of conventional teaching as contrasted with the "secondary stability" of the sleeker canoe design, one which allows eventu-

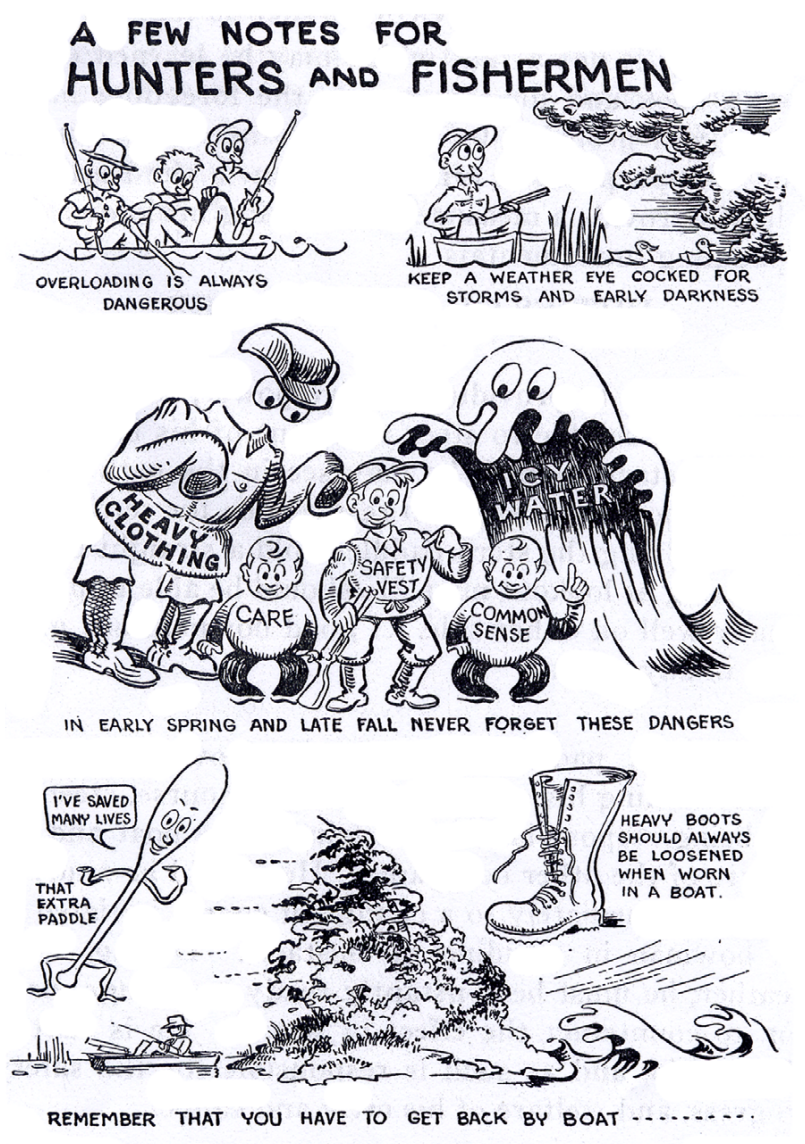

Figure $2^{3}$

al greater performance and freedom of movement for the paddler just as learning-centred pedagogy leads to greater student autonomy over time.

\section{Personal Metaphors for Teaching}

After the conference, the workshop facilitators contacted the participants by e-mail to ask them if they used metaphors as a way of thinking about their teaching. Participants subsequently identified cycling, rock-climbing, cooking, gardening, and geocaching as metaphors they had adopted for teaching on higher education. The authors have worked with the brief descriptions of these metaphors submitted by professors from British Columbia, Alberta, and Ontario to add to the canoeing metaphor, which served as the basis for the workshop (See Appendix A).

\footnotetext{
${ }^{3}$ Reprinted from The Canoe and You (p. 35), by R. H. Perry, 1948, Toronto: J. M. Dent \& Sons Ltd.
} 


\section{Conclusion}

The authors set out to provide university and college professors with a unique active learning setting to explore canoeing as a metaphor for teaching and learning in higher education. In so doing, the workshop facilitators hoped to stimulate reflection on approaches to teaching in a challenging and collaborative environment. Nearly twenty men and women, including freshly-minted $\mathrm{PhDs}$, mid-career professors and senior faculty, and possessing highly varied experience levels as paddlers, eagerly took the plunge (although not, thankfully, literally) along the banks of the St. John River in New Brunswick. They reportedly enjoyed the setting, the outing, the dialogue, and the opportunity to use their imaginations and to express their ideas about teaching in an outdoor environment. An academic at Duke University suggests that conducting class beyond the confines of campus can "interrupt...the programming of classroom conditioning” and stimulate a more holistic educational process (Tompkins, 1996, as cited in "Service Learning," 2009). Does this benefit apply to the ongoing professional development of teaching faculty? The authors of this article contend that it does.

What further lessons did the authors derive from their venture into the out-of-doors to explore the application of metaphors to teaching in higher education? Many of the lessons are a variation of the lessons of more traditional workshops writ large. First and foremost, off-site workshops require detailed and long-term planning and the support of specialists who operate and rent equipment and facilities. Second, a site visit is essential prior to the activity. Third, participants may be required to sign waivers at the site. Fourth, videotaped recordings of the event, especially of the small group presentations, can provide valuable and more precise tracking of visual and oral contributions for follow-up and written accounts (such as the present essay). Fifth, we are reminded that activities do not always go as smoothly as planned and that the level of physical, emotional, psychological, and inter-personal risk are greater both for participants and for the facilitators in less conventional learning settings. Although there were no major mishaps, the facilitators would finetune the planning of several aspects of the activity in future iterations to minimize certain unnecessary difficulties. ${ }^{4}$ Finally, a three-hour workshop, although valuable and even memorable unto itself, is likely to have a greater impact if participants are drawn in to further reflection, reading, writing, and active dialogue on the subject at hand in the months to follow the activity.

\section{References}

Gassner, G.J. (1999). Using metaphors for highperformance teaching and coaching. Journal of Physical Education, Recreation, and Dance, 70(7), 33-36.

Johnson, M. (1987). The body in the mind. Chicago: University of Chicago Press.

Kasoutas, M. \& Malamitsa K. (2009). Exploring Greek teachers' beliefs using metaphors. Australian Journal of Teacher Education, 34(2). Retrieved from http://ajte.education.ecu. edu.au/issues/PDF/342/Kasoutas.pdf

Kolb, D.A. (1984). Experiential learning: Experience as the source of learning and development. New Jersey: Prentice-Hall.

Lakoff, G. \& Johnson, M. (1980). Metaphors we live by. Chicago: University of Chicago Press.

Lim, C.S. (1999). Using metaphor analysis to explore adults' images of mathematics. Philosophy of Mathematics Education Journal, 12.

McDonald, A. (1986). Metaphor, self-image and

\footnotetext{
${ }^{4}$ A participant fell (without injury) when a canoe was pulled up a slippery embankment. Workshop leaders could have been more conscious of ability and experience when canoe pairs were formed.
} 
the writing teacher. The Quarterly, 8(2). Retrieved from http://www.nwp.org/cs/public/ download/nwp_file/1857/Metaphor_SelfImage_and_the_Writing_Teacher.pdf?x$\mathrm{r}=$ pcfile_d

Perry, R.H. (1948). The canoe and you. Toronto: J.M. Dent \& Sons Ltd.

Service learning. (2009). Retrieved from St. Francis Xavier University web-site at: http://www. stfx.ca/academic/servicelearning/

Thornbury, S. (1991). Metaphors we work by: EFL and its metaphors. ELT Journal, 45(3), 193200.

\section{Biographies}

W. Alan Wright is Vice-Provost, Teaching and Learning, at the University of Windsor. The role of educational developers in fostering student success in higher education is one focus of his research interests.

Marie-Jeanne Monette is a research assistant at the University of Windsor. Her field of research is the success and perseverance of students in post-secondary studies.

Beverley Hamilton is the Assistant to the Vice-Provost, Teaching and Learning, at the University of Windsor, Ontario. Her pedagogical research interests include the use of metaphor as a tool for reflective practice, the role of narrative identity in teaching and learning, and collaborative approaches to institutional change. 


\section{Appendix A}

\section{Original Metaphors for Teaching and Learning in Higher Education}

\begin{tabular}{|c|c|c|}
\hline Activity & Components of the activity & Parallels in teaching \\
\hline Cycling & $\begin{array}{ll}\text { - } & \text { Plan your cycling route } \\
\text { - } & \text { Unexpected change in wind } \\
\text { direction } \\
\text { - } & \text { Adjust to conditions } \\
\text { - } & \text { Keep the flow } \\
\text { - } & \text { Mental and physical challenge } \\
\text { - } & \text { and reward } \\
& \text { Self-fulfilment }\end{array}$ & $\begin{array}{ll}\text { - } & \text { Plan your lesson } \\
\text { - } & \text { Unexpected developments with } \\
\text { class } & \\
\text { - } & \text { Adapt with student feedback and } \\
& \text { colleague support } \\
\text { - } & \text { Exhilaration, clarity and purpose } \\
\text { - } & \text { Seek solace in balance of } \\
\text { challenge and reward } \\
\text { - } & \text { Self-fulfilment }\end{array}$ \\
\hline Geocaching & 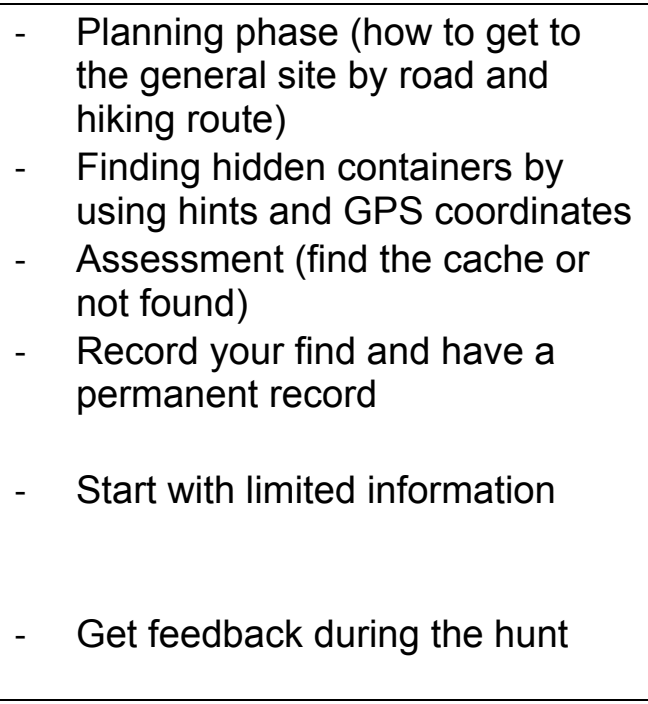 & 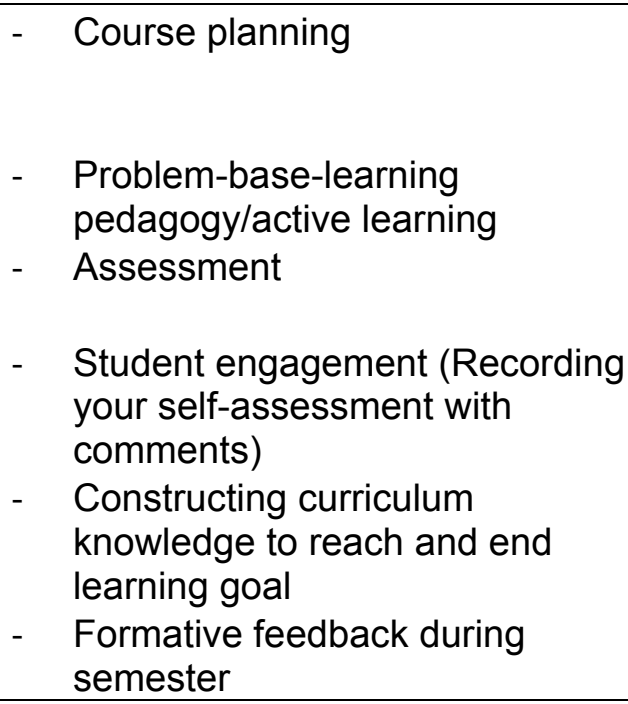 \\
\hline $\begin{array}{l}\text { Cooking, Serving, } \\
\text { Eating }\end{array}$ & 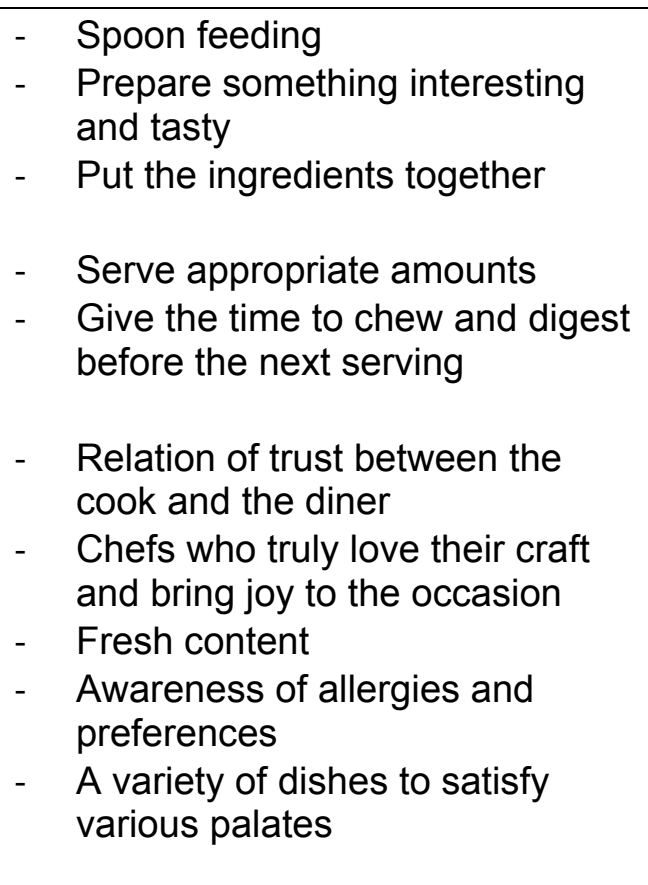 & $\begin{array}{ll}\text { - } & \text { Eliminate choices for students } \\
\text { - } & \text { Prepare interesting lessons } \\
\text { - } & \text { How we will deliver the material, } \\
\text { subject, lesson } \\
\text { - } \quad \text { Right amount of information } \\
\text { - } \quad \text { Give students time to } \\
\text { comprehend the material before } \\
\text { giving more } \\
\text { - } \quad \text { Trust between professor and } \\
\text { students } \\
\text { - Show that you love your subject } \\
\text { and teaching } \\
\text { - } \quad \text { Up to date material } \\
\text { - } \quad \text { Know your students; } \\
\text { background, learning styles } \\
\text { - Variety of teaching styles to } \\
\text { accommodate different learning } \\
\text { styles }\end{array}$ \\
\hline
\end{tabular}




\begin{tabular}{|c|c|c|}
\hline Rock Climbing & $\begin{array}{l}\text { Guidance, support, freedom to } \\
\text { learn: } \\
\text { - Not pulled up the wall nor left to } \\
\text { free fall but just enough rope to } \\
\text { explore freely } \\
\text { - } \quad \text { Readjustment and changing of } \\
\text { approach } \\
\text { Success comes from: } \\
\text { - Reaching higher than the } \\
\text { day before } \\
\text { - Triumph of figuring the route } \\
\text { out } \\
\text { - Hard work to grasp new } \\
\text { heights. }\end{array}$ & $\begin{array}{l}\text { Guidance, support, freedom to } \\
\text { learn: } \\
\text { - } \quad \text { Teaching to give students space } \\
\text { to learn on their own } \\
\text { - } \quad \text { Adjusting and changing if } \\
\text { necessary } \\
\text { Success comes from: } \\
\text { - Looking to improve } \\
\text { - Finding solution and better } \\
\text { ways to teach } \\
\text { - Students must apply } \\
\text { themselves to reach new } \\
\text { levels of understanding }\end{array}$ \\
\hline Gardening & $\begin{array}{l}\text { - } \quad \text { Plan your garden } \\
\text { - } \quad \text { Take into account the seasons } \\
\text { - } \text { Respond to the weather } \\
\text { - } \text { Adjust to soil conditions } \\
\text { - Plant } \\
\text { - } \text { Remove weeds } \\
\text { - Harvest } \\
\text { - Eat the produce }\end{array}$ & $\begin{array}{ll}\text { - } & \text { Plan your course or lesson } \\
\text { - } & \text { Take into account the broader } \\
\text { context and climate } \\
\text { - }\end{array}$ \\
\hline
\end{tabular}

The authors wish to acknowledge the contributions of the following workshop participants who submitted their personal metaphors for teaching: Natasha Kenny, University of Guelph (cycling); Gary Hunt, Thompson Rivers University, (geocaching); Billy Strean, University of Alberta (cooking, serving, eating); Carolyn Hoessler, Queen's University (rock climbing); and Alice Macpherson, Kwantlen Polytechnic University (gardening). 